\title{
A Di-Carbazole-Based Dye as a Potential Sensitizer for Greenhouse-Integrated Dye-Sensitized Solar Cells
}

\author{
Dimitris A. Chalkias ${ }^{1}$, Christos Charalampopoulos ${ }^{2}$, Stefania Aivali ${ }^{2}$, Aikaterini K. Andreopoulou ${ }^{2} \mathbb{1}$, \\ Aggeliki Karavioti ${ }^{1,3}$ and Elias Stathatos ${ }^{1, *}$ \\ 1 Nanotechnology \& Advanced Materials Laboratory, Department of Electrical and Computer Engineering, \\ University of Peloponnese, GR26334 Patras, Greece; chalkias@mech.upatras.gr (D.A.C.); \\ a.karavioti@gmail.com (A.K.) \\ 2 Department of Chemistry, University of Patras, GR26504 Rio-Patras, Greece; \\ charalampopoulosch@gmail.com (C.C.); aivali.s@upnet.gr (S.A.); andreopo@upatras.gr (A.K.A.) \\ 3 Department of Physics, University of Patras, GR26504 Rio-Patras, Greece \\ * Correspondence: estathatos@uop.gr
}

\section{check for} updates

Citation: Chalkias, D.A.; Charalampopoulos, C.; Aivali, S.; Andreopoulou, A.K.; Karavioti, A.; Stathatos, E. A Di-Carbazole-Based Dye as a Potential Sensitizer for Greenhouse-Integrated Dye-Sensitized Solar Cells. Energies 2021, 14, 1159. https://doi.org/ 10.3390/en14041159

Academic Editors: Nadia Barbero, Claudia Barolo and Frédéric Sauvage

Received: 20 January 2021

Accepted: 16 February 2021

Published: 22 February 2021

Publisher's Note: MDPI stays neutral with regard to jurisdictional claims in published maps and institutional affiliations.

Copyright: (c) 2021 by the authors. Licensee MDPI, Basel, Switzerland. This article is an open access article distributed under the terms and conditions of the Creative Commons Attribution (CC BY) license (https:// creativecommons.org/licenses/by/ $4.0 /)$.

\begin{abstract}
For the first time in dye-sensitized solar cell (DSSC) technology, a di-carbazole-based dye was synthesized and evaluated for its usage as a potential sensitizer for the development of wavelength selective semi-transparent DSSCs for greenhouses-oriented applications. The dye was designed to demonstrate a blue light absorption, allowing a high transmittance in the red region of the visible light, even after its adsorption on the anode semiconductor, which is the most important one for the photosynthetic action of the plants. The application of the new dye to DSSCs was examined using either a high-performance iodide-based electrolyte or a highly transparent iodine-free electrolyte to determine a good balance between electric power generation and device transparency. The spectral engineered DSSCs demonstrated quite promising characteristics, providing a high external quantum efficiency (higher than 70\%) in the whole blue-green region of the visible light, while allowing high transparency (up to 55\%) in the red region, where the second peak in the absorbance spectrum of chlorophyll is located. Finally, the derived results were discussed under the consideration of important metrics for this niche application, including the transparency of the solar cells in the region of photosynthetic active radiation and the attained crop growth factor. The present work constitutes one of the few comprehensive studies carried out up to now in the direction of the development of 3rd generation "agrivoltaics" for their possible integration as cladding materials in energy-autonomous greenhouses.
\end{abstract}

Keywords: dye-sensitized solar cell; di-carbazole; iodine-free electrolyte; spectral engineering; greenhouse

\section{Introduction}

The combination of the extreme growth of the earth population, global warming, and increased scarcity of food and fresh water are expected to put significant stress on conventional agriculture in the years to come [1]. On the other hand, global energy needs are growing exponentially and are forecast to increase by $50 \%$ until 2050 [2]. For this reason, humanity must soon find sustainable approaches to relieve this impending crisis. In this direction, greenhouse-based agriculture can increase annual crop production and reduce water consumption, providing a suitable environment for the growth of plants, irrespective of the outdoor environment. However, the operation of greenhouses comes with its own set of challenges, with one of the most important to be the meeting of their energy demands, which can constitute the highest percentage of a greenhouse environmental impact [3]. By taking into account the aforementioned, the development of energy-autonomous greenhouses is found as a sustainable approach. Integrating solar power with greenhouses using 
the so-called "agrivoltaics", namely photovoltaics (PVs) for agriculture, is considered a new hot topic for research and development.

Approaches of greenhouse-integrated solar cells can be categorized to adjacent, shared structure, and shared structure and sunlight systems. Given that the land usage efficiency is of increasing importance in our days, along with the preference for co-locating agriculture and population centers, systems that share the same land are considered ideal [4]. In this direction, employing opaque solar modules on the roof of greenhouses is one possible strategy. However, this situation results in crop yield loss since the solar cells prevent light absorption by the plans [5]. To overcome this drawback, modern strategies, where sunlight over the photosynthetically active radiation (PAR) $(400-700 \mathrm{~nm})$ region continues to reach the plants, while the remaining portion is used for electric power generation by solar cells, are under consideration. For this combinatorial approach, new emerging PV technologies, such as organic photovoltaics and DSSCs, are the candidates of choice, since they offer large flexibility in their spectral characteristics [6]. In addition, DSSCs offer distinct advantages over the other PV technologies, such as high transparency, large area coverage, very good performance in diffuse light conditions, and low cost.

Ever since the first modern DSSC device was developed by Brian O'Regan and Michael Grätzel in 1991 [7], many research teams have been involved and contributed to the vast evolution of this type of PV technology. Today, a series of new materials and device architectures are provided, attaining, in many cases, the desired characteristics regarding the efficiency, stability, and cost for their intended application [8]. However, regarding the niche application of greenhouses, the investigations are only few, with the technology of greenhouse-integrated DSSCs to have great room for improvements. In this direction, most of the investigations deal with the dye-sensitizer, since this is the heart of the DSSCs and determines their absorption spectrum [9-12].

Up to now, many different types of dyes have been synthesized and evaluated as sensitizers for DSSCs. Amongst them, the ruthenium-based metal complexes are the benchmark, since they lead to the highest energy conversion efficiencies. However, the necessity for abundant metal-free sensitizers is well recognized [13]. In this direction, metal-free, fully organic dyes are promising alternatives, since they are environmentally and economically beneficial, which is especially appreciated when dealing with large-area DSSC panels. Typically, metal-free dyes are based on moieties such as carbazole [14], triphenylamine [15], phenothiazine [16], indoline [17], etc., resulting even in efficiencies of around 10\% in some cases [18]. More recently, Zhang et al. presented a new metal-free organic dye with a record efficiency of almost 13\% [19].

Amongst metal-free organic substances, carbazoles are efficient electron donors and hole transporters. In general, carbazole is a widely used electron donor with unique optoelectronic properties that makes it a valid candidate for many applications, such as OLEDs [20], PVs [21], photorefractive materials [22], etc. Carbazole is appreciated for its low cost and its fully aromatic structure, allowing versatile and easy modifications. The nitrogen atom and the fused phenyl groups of carbazole provide many sites for substitutions that can affect the optoelectronic properties of the material. For example, introducing an aromatic ring fusion strategy is a burgeoning option to improve the molar absorption coefficient and expand the $\pi$-system of the donor moiety to obtain long-wavelength absorption [23]. On the other hand, the binding of two carbazole molecules through the nitrogen atoms results in the synthesis of $9,9^{\prime}$-dicarbazole. This molecule has a large dihedral angle of about 70 degrees between the two-carbazole groups [24], while it has been already used as a building block for conjugated microporous polymers [25] and covalent organic networks [26]. Although this structure is particularly interesting and versatile, only a few studies are reported with 9,9'-'dicarbazole derivatives to be employed in solar cells. For DSSCs, many different carbazoles or carbazole derivative dyes have been used up to now as sensitizers of the anodes of these photo-electrochemical cells. In some cases, the results are quite promising, with the energy conversion efficiency of these solar cells to exceed even $10 \%[23,27]$. However, most of these cases cannot be considered for green- 
houses integration because of the interference of the absorption spectrum of the solar cells with the absorption spectrum of chlorophyl.

In the present study, in an effort to develop a low-cost organic dye for DSSCs that are to be implemented as greenhouse cladding materials, a di-carbazole $(\mathrm{Cz}-2)$ dye was synthesized and evaluated for its application to solar cells. The new dye was synthesized with a di-carbazole electron-donor central core and periphery cyanoacrylic acid anchoring groups that furthermore serve as electron transporting bridges of the charge carriers generated in the carbazole-based central cores to the anode semiconductor. The organic dye was fully characterized regarding its structural, thermal, optical, and electrochemical characteristics via various complementary techniques. Its application to DSSCs was also evaluated thoroughly, using either a high-performance iodide-based electrolyte or a highly transparent iodine-free electrolyte, to determine a good balance between electric power generation and device transparency. Finally, the derived results were discussed by taking into account important metrics for greenhouses application, including the transparency of the solar cells in the PAR region and the attained crop growth factor.

\section{Materials and Methods}

\subsection{Materials}

For the dye synthesis: 2,2' $, 7,7^{\prime}$-tetrakis(4,4,5,5-tetramethyl-1,3,2-dioxaborolan-2-yl)-9,9' bicarbazole [28] and the catalyst palladium(II) tetrakis triphenyl phosphine $\left[\mathrm{Pd}\left(\mathrm{PPh}_{3}\right)_{4}\right]$ [29] were prepared according to the procedures described in the literature. All solvents and reagents were purchased from Sigma Aldrich, Alfa Aesar, or Acros Organics, and they were used without further purification unless otherwise stated. For the preparation of the $\mathrm{I}_{2}-$ based and $\mathrm{I}_{2}$-free electrolyte: 1-methyl-3-propylimidazolium iodide (purity $98 \%$, Alfa Aesar), lithium iodide (purity 99.9\%, Sigma Aldrich), iodine (purity $>99.5 \%$, Fisher Chemical), 4 tertbutylpyridine (purity 96\%, Sigma Aldrich), guanidine thiocyanate (purity $\geq 97 \%$, Sigma Aldrich), acetonitrile (purity 99.9\%, Merck), and valeronitrile (purity 99.5\%, Sigma Aldrich) were used. For the fabrication of the DSSCs: fluorine-doped tin oxide glass (TEC 8, Pilkington), titania paste for blocking layer (BL-1 Blocking Layer, Dyesol), titanium dioxide nano-powder (P25, Degussa), titanium (IV) chloride (purity $\geq 99 \%$, Sigma Aldrich), synthesized Cz-2-based dye, tetrahydrofuran (analytical reagent grade, Fisher Chemical), homemade $\mathrm{I}_{2}$-based and $\mathrm{I}_{2}$-free liquid state electrolytes, platinum paste (PT1, Dyesol), low-temperature thermoplastic sealant (50 $\mu \mathrm{m}$ thickness, Dyesol), and silver paste (Electrodag 1415, Agar Scientific) were used.

\subsection{Synthetic Route of the Di-Carbazole-Based Dye}

The synthetic route of the Cz-2 dye is schematically presented in Figure 1 and discussed in detail below.

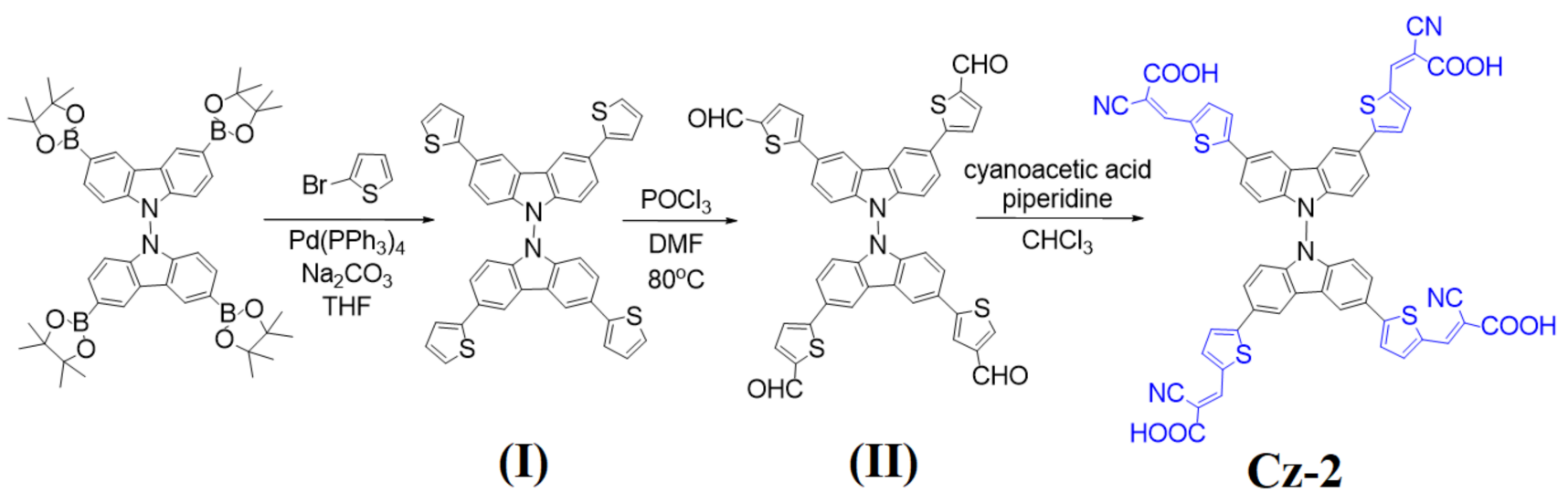

(II)

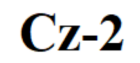

Figure 1. Synthetic route for the preparation of $\mathrm{Cz}-2$ dye.

Synthesis of (I): In a round-bottom flask were placed 2,2',7,7'-tetrakis (4,4,5,5-tetramethyl1,3,2-dioxaborolan-2-yl)-9,9'-bicarbazole (200 mg, $0.24 \mathrm{mmol})$, 2-bromothiophene (163 mg, 
$1.20 \mathrm{mmol}), \mathrm{Pd}\left(\mathrm{PPh}_{3}\right)_{4}(23 \mathrm{mg}, 0.02 \mathrm{mmol})$, and THF $(6 \mathrm{~mL})$. The mixture was degassed and filled with argon; then, an aqueous solution of $2 \mathrm{M} \mathrm{Na}_{2} \mathrm{CO}_{3}(2 \mathrm{~mL})$ was added. The reaction mixture was refluxed under argon and vigorous stirring for $48 \mathrm{~h}$. After cooling to room temperature, the precipitated solid was filtrated and washed repeatedly with $\mathrm{MeOH}$ and $\mathrm{H}_{2} \mathrm{O}$. The produced crude product was dissolved in toluene and filtrated for the removal of any catalyst traces. Evaporation of the solvent afforded the pure product (I) as a white powder. Yield: $90 \mathrm{mg}, 56 \% .{ }^{1} \mathrm{H}$ NMR $\left(\mathrm{CDCl}_{3}, \delta \mathrm{ppm}\right): 6.94(\mathrm{~d}, 4 \mathrm{H}), 7.13$ (two d, $\left.4 \mathrm{H}\right), 7.30(\mathrm{~d}, 4 \mathrm{H})$, $7.37(\mathrm{~d}, 4 \mathrm{H}), 7.63(\mathrm{dd}, 4 \mathrm{H}), 8.46(\mathrm{~s}, 4 \mathrm{H})$.

Synthesis of (II): In a round-bottom flask were added (I) $(70 \mathrm{mg}, 0.11 \mathrm{mmol})$, dry DMF $(8 \mathrm{~mL})$, and $\mathrm{POCl}_{3}(0.1 \mathrm{~mL})$. The mixture was heated under argon at $80{ }^{\circ} \mathrm{C}$ for $24 \mathrm{~h}$. After the reaction completion, $\mathrm{H}_{2} \mathrm{O}$ was added, and the organic phase was extracted, washed with $\mathrm{H}_{2} \mathrm{O}$, and dried over $\mathrm{MgSO}_{4}$. Removal of the drying agent, evaporation of the solvent, and washing of the solid with $\mathrm{MeOH}$ afforded the pure product. Yield: $40 \mathrm{mg}, 48 \%$. ${ }^{1} \mathrm{H} \mathrm{NMR}\left(\mathrm{CDCl}_{3}, \delta \mathrm{ppm}\right): 6.96(\mathrm{~d}, 4 \mathrm{H}), 7.48$ (two d, 4H), $7.66(\mathrm{~d}, 4 \mathrm{H}), 7.78$ (broad, 4H), $8.55(\mathrm{~s}, 4 \mathrm{H}), 9.91(\mathrm{~s}, 4 \mathrm{H})$.

Synthesis of Cz-2 dye: To a solution of (II) $(40 \mathrm{mg}, 0.05 \mathrm{mmol})$ in $\mathrm{CHCl}_{3}(6 \mathrm{~mL})$ were added 2-cyanoacetic acid (50 $\mathrm{mg}, 0.59 \mathrm{mmol})$ and piperidine $(0.2 \mathrm{~mL})$, and the reaction mixture was refluxed under argon for $48 \mathrm{~h}$. After the completion of the reaction, $\mathrm{H}_{2} \mathrm{O}$ was added, and the organic layer was extracted, washed with $\mathrm{H}_{2} \mathrm{O}$ and finally with $20 \%$ aq. $\mathrm{HCl}$, leading to the precipitation of the crude product. This was collected by filtration, washed repeatedly with $\mathrm{H}_{2} \mathrm{O}$ and $\mathrm{MeOH}$, and dried under high vacuum, affording the desired $\mathrm{Cz}-2$ dye as an orange powder. Yield: $33 \mathrm{mg}, 61 \% .{ }^{1} \mathrm{H}$ NMR (DMSO-d6, $\delta$ ppm): 6.99 (broad, $4 \mathrm{H}), 7.54$ (broad, 4H), 7.67 (broad, $4 \mathrm{H}), 7.82$ (broad, $4 \mathrm{H}), 8.05$ (s, 4H), 8.93 (broad, $4 \mathrm{H})$.

\subsection{Fabrication of the Dye-Sensitized Solar Cells}

DSSCs of $0.25 \mathrm{~cm}^{2}$ active area were fabricated according to the following procedure. The dye-sensitized working electrodes consisted of an ultra-thin compact $\mathrm{TiO}_{2}$ film (blocking layer) and a thin mesoporous $\mathrm{TiO}_{2}$ film sensitized with the dye (main active layer). The blocking layer was fabricated by spin-coating the BL-1 Blocking layer paste on the fluorine-doped tin oxide (FTO) glass at $1500 \mathrm{rpm}$, while its calcination was carried out at $500^{\circ} \mathrm{C}$ for $60 \mathrm{~min}$. The main active layer was fabricated on the top of the blocking layer by spin-coating a $\mathrm{TiO}_{2}$ paste that was prepared as reported in previous work [30]. Its sintering was carried out at $550^{\circ} \mathrm{C}$ for $90 \mathrm{~min}$, followed by gradual cooling to room temperature, leading to uniform semi-transparent mesoporous films, without cracks and peeling-off from the substrate. The thickness of the mesoporous $\mathrm{TiO}_{2}$ film was adjusted at about $15 \mu \mathrm{m}$, which is about the optimal thickness for photo-anodes of DSSCs employing ruthenium-based dyes and $\mathrm{I}_{2}$-based electrolytes [31-33]. Subsequently, a $\mathrm{TiCl}_{4}$ treatment of the nanostructured working electrodes was conducted, by immersing them into a $40 \mathrm{mM} \mathrm{TiCl}{ }_{4}$ aqueous solution at $70^{\circ} \mathrm{C}$ for $30 \mathrm{~min}$, followed once again by their calcination at $500^{\circ} \mathrm{C}$ for $30 \mathrm{~min}$ and their gradual cooling to room temperature. The dye-sensitization of the anode was carried out by their immersion into a $0.3 \mathrm{mM} \mathrm{Cz}-2$ dye tetrahydrofuran (THF) solution for $12 \mathrm{~h}$, at room temperature. The counter electrodes of the solar cells were fabricated by doctor-blading the PT1 paste on the FTO glasses, while their calcination was carried out at $500^{\circ} \mathrm{C}$ for $30 \mathrm{~min}$. Finally, the dye-sensitized working electrodes were sandwiched with the counter electrodes, using a low-temperature thermoplastic spacer/sealant of $50 \mu \mathrm{m}$ thickness. The sealing procedure was carried out at $120^{\circ} \mathrm{C}$ for $15 \mathrm{~min}$ under pressure given by two clips. The intervening space was filled with a liquid state $\mathrm{I}_{2}$-based electrolyte $(0.6 \mathrm{M}$ 1-methyl-3-propylimidazolium iodide, $0.03 \mathrm{M}$ iodine, $0.5 \mathrm{M}$ 4-tertbutylpyridine, $0.1 \mathrm{M}$ guanidine thiocyanate, in a mixture of acetonitrile and valeronitrile (volume ratio: $85: 15)$ ) or $\mathrm{I}_{2}$-free electrolyte $(0.1 \mathrm{M}$ lithium iodide, $0.6 \mathrm{M}$ 1-methyl-3-propylimidazolium iodide, $0.5 \mathrm{M}$ 4-tertbutylpyridine, $0.1 \mathrm{M}$ guanidine thiocyanate, in a mixture of acetonitrile and valeronitrile (volume ratio: 85:15)), through one hole that was already drilled to the counter electrodes. A special vacuum and filling syringe facilitated the procedure. The fabrication process of the solar cells was completed by sealing this hole using an extra piece of glass, 
under the same sealing conditions. The contacts of the solar cells were made by silver, using Electrodag 1415 silver paste, to collect the current efficiently. In all cases, a proper shading mask, equal to the active area of solar cells, was used to prevent the light incidence from the edges [34].

\subsection{Characterization Methods}

${ }^{1} \mathrm{H}$ spectra were recorded on a Bruker Advance (Bruker BioSpin GmbH, Magnet Division, Karlsruhe, Germany) DPX $600 \mathrm{MHz}$ spectrometer with $\mathrm{CDCl}_{3}$ or DMSO- $\mathrm{d}_{6}$ as solvents. Thermogravimetric analysis (TGA) was conducted on samples of $6 \mathrm{mg}$ contained in alumina crucibles in a Labsys TM TG apparatus of Setaram, at a heating rate of $10^{\circ} \mathrm{C} / \mathrm{min}$, under nitrogen. Ultraviolet-visible (UV-Vis) spectra of solutions were recorded using a Hitachi U-1800 spectrophotometer. The photoluminescence (PL) spectra of solutions were recorded using a Perkin Elmer LS45 luminescence spectrometer, after excitation at the absorption maxima.

The electrochemical characteristics of the as-synthesized materials were determined by cyclic voltammetry $(\mathrm{CV})$ measurements carried out in a three-electrode cell; a platinum wire served as the counter electrode and an $\mathrm{Ag} / \mathrm{AgCl}$ electrode served as the reference electrode. Tetrabutylammonium hexafluorophoshate $\left(\mathrm{TBAPF}_{6}\right) 0.1 \mathrm{M}$ in acetonitrile $\left(\mathrm{CH}_{3} \mathrm{CN}\right)$ was used as the supporting electrolyte. Thin films of the synthesized materials were fabricated on FTO-coated glass slides, $\left(\mathrm{R}_{\text {sheet }}<15 \mathrm{Ohm} / \mathrm{sq}\right)$, preheated at $80{ }^{\circ} \mathrm{C}$ for $20 \mathrm{~min}$, from precursor solutions of THF, and further annealed at $80^{\circ} \mathrm{C}$ for $15 \mathrm{~min}$. For the data collection and analysis, an Autolab PGSTAT $302 \mathrm{~N}$ electrochemical analyzer connected to a computer running the NOVA 1.8 software were used. All experiments were carried out at a scan rate of $0.1 \mathrm{~V} / \mathrm{s}$. Before the measurements, the cell was purged for 20 min with pure argon to remove the diluted gasses. The potential of the reference electrode was calibrated with respect to Ferrocene/Ferrocenium.

Diffuse reflectance spectroscopy (DRS) measurements were recorded on the dyesensitized working electrodes using an interval wavelength of $1 \mathrm{~nm}$, from 300 to $800 \mathrm{~nm}$, using a Jasco V-770 spectrophotometer equipped with a $60 \mathrm{~mm}$ integrating sphere, embedding a $\mathrm{PbS}$ detector (ISN-923). UV-VIS transmittance spectroscopy measurements were recorded on the solar cells using an internal wavelength of $2 \mathrm{~nm}$, from 300 to $800 \mathrm{~nm}$, using a Hitachi U-2900 spectrophotometer. The characterization of the solar cells was carried out under standard test conditions $\left(1000 \mathrm{~W} / \mathrm{m}^{2}\right.$, AM $\left.1.5 \mathrm{G}, 25^{\circ} \mathrm{C}\right)$, using a solar light $(16 \mathrm{~S}-300)$ solar simulator calibrated by a reference cell consisting of monocrystalline silicon (Newport 919P-003-10); the current density-voltage $(J-V)$ curves of the solar cells were recorded using a Keithley 2601 source meter. Incident photon-to-electron conversion efficiency (IPCE) of the solar cells was determined by a ThetaMetrisis PM-QE equipped with a Xenon (Xe) light source, using a filter monochromator (Oriel Cornerstone ${ }^{\mathrm{TM}} 260$ 1/4 m, Newport), which was controlled by the PM-Monitor ${ }^{\circledR}$ software; the IPCE measurements were carried out using an interval wavelength of $5 \mathrm{~nm}$ and a delay time of $0.2 \mathrm{~s}$, from 300 to $800 \mathrm{~nm}$. Electrochemical impedance spectroscopy (EIS) measurements were carried out on the solar cells using a Metrohm Autolab 3.v potentiostat galvanostat (Model PGSTAT 128 N); the measurements were recorded in the dark, at $-V_{O C}$ forward bias, using a perturbation of $\pm 10 \mathrm{mV}$, over the frequency range from $100 \mathrm{kHz}$ to $0.1 \mathrm{~Hz}$, at room temperature.

\section{Results}

\subsection{Synthesis of the Di-Carbazole-Based Dye}

As it is mentioned before, the present work aims to synthesize a low-cost sensitizer for DSSCs that can provide suitable optical characteristics for greenhouses application, i.e., the solar cells to demonstrate low light absorption in the spectral regions where chlorophyll absorbs. In this direction, a di-carbazole-based dye was designed and synthesized. More specifically, the central core of the $9,9^{\prime}$-dicarbazole organic dye was prepared from the oxidation of the nitrogen atom of commercial 3,6-dibromo-carbazole using potassium permanganate $\left(\mathrm{KMnO}_{4}\right)$ in acetone $[25,35]$. The four bromine atoms 
of 3,3',6,6'-tetrabromo- $N, N^{\prime}$-bicarbazole were substituted with pinacolato boronic ester moieties through palladium-catalyzed reaction with bis(pinacolato)diboron, in 1,4-dioxane, in the presence of potassium acetate as a base [28]. Ongoing, this pinacolato boronic acid bearing intermediate reacted under palladium-mediated Suzuki coupling conditions with 2-bromo-thiophene (intermediate (I)) and then, the thiophene periphery end-groups reacted with phosphorus oxychloride in dimethylformamide, affording the formyl-functionalized molecule (intermediate (II)). Finally, the periphery aldehyde groups were converted to cyanoacrylic acid groups under Knoevenagel condensation conditions with 2-cyanoacetic acid, in the presence of piperidine in chloroform. The investigation of the thermal characteristics of the $\mathrm{Cz}-2$ dye was performed via TGA, as shown in Figure 2. The Cz-2 dye was found to be thermally stable up to $230^{\circ} \mathrm{C}$, which is sufficient for its application as a sensitizer of DSSCs.

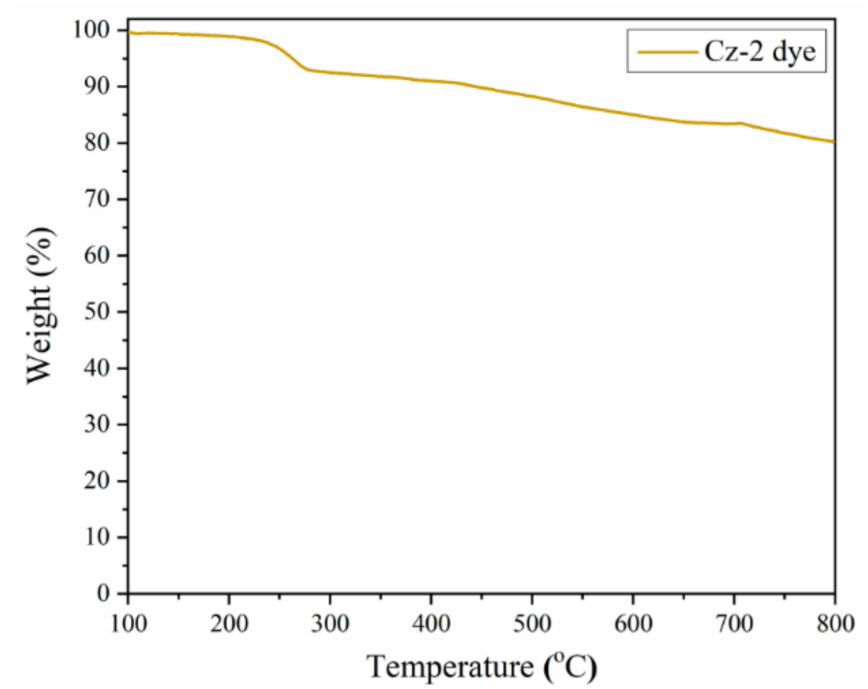

Figure 2. Thermogravimetric analysis (TGA) thermogram of the $\mathrm{Cz}-2$ dye.

\subsection{Optical and Electrochemical Characteristics of the Di-Carbazole-Based Dye}

The UV-Vis absorption and PL spectra of the synthesized dye in tetrahydrofuran (THF) solution are shown in Figure 3 in comparison with their respective precursor intermediate (I). As it is observed, the Cz-2 dye showed absorption peaks that are located at 305 and $420 \mathrm{~nm}$ (Figure 3a). Obviously, the new peak appearing at $420 \mathrm{~nm}$, when compared to the precursor intermediate (I), is owing to the extended conjugation of the cyanoacrylic acid groups. The emission spectrum of the dye in THF solution, when excited at the absorption maxima, presents an emission maximum at $540 \mathrm{~nm}$ (Figure 3b). Moreover, an emission peak at $405 \mathrm{~nm}$ is also presented when the dye was excited at $305 \mathrm{~nm}$, which is almost at the same wavelength where the emission of the intermediate (I) is located when it was excited at the same wavelength. Furthermore, by comparing the absorption spectrum of the dye with the $\mathrm{McCree}$ action spectrum (which represents the average photosynthetic response of plants to light), it is shown that there is low spectral interference, showing the suitability of the synthesized dye for the fabrication of greenhouse-integrated DSSCs [36].

Regarding the electrochemical characteristics of the $\mathrm{Cz}-2$ dye, Figure 4a presents the CV curves derived using the dye in the film form on the FTO glass, serving as the working electrode, Figure $4 \mathrm{~b}$ is a schematic depiction of the energy levels of the dye and the remaining components of the DSSC, while the electrochemical characteristics are also tabulated in Table 1. As it is observed, the dye presents oxidation at around 1.2-1.4 eV (vs. $\mathrm{Ag} / \mathrm{AgCl}$ ). The highest occupied molecular orbital (HOMO) energy level of the dye was determined from the first oxidation onset using Equation (1). On the other hand, since carbazoles are strong electron donors, their reduction onset is not always reliable [21,37]. Thus, their lowest unoccupied molecular orbital (LUMO) energy levels were calculated 
from their respective HOMO levels and the optical band gap $\left(E_{g, o p t}\right)$ using Equation (2). The $E_{g, o p t}$ of the dye was calculated using Equation (3) and found at $2.56 \mathrm{eV}$.

$$
\begin{gathered}
E_{\text {HOMO }}=-e\left(E_{\text {ons }}^{o x}-E_{1 / 2}^{F c}\right)-5.2[e V] \\
E_{L U M O}=E_{g, o p t}+H_{\text {HOMO }} \\
E_{g, o p t}=\frac{1240}{\lambda_{\text {onset }}}
\end{gathered}
$$
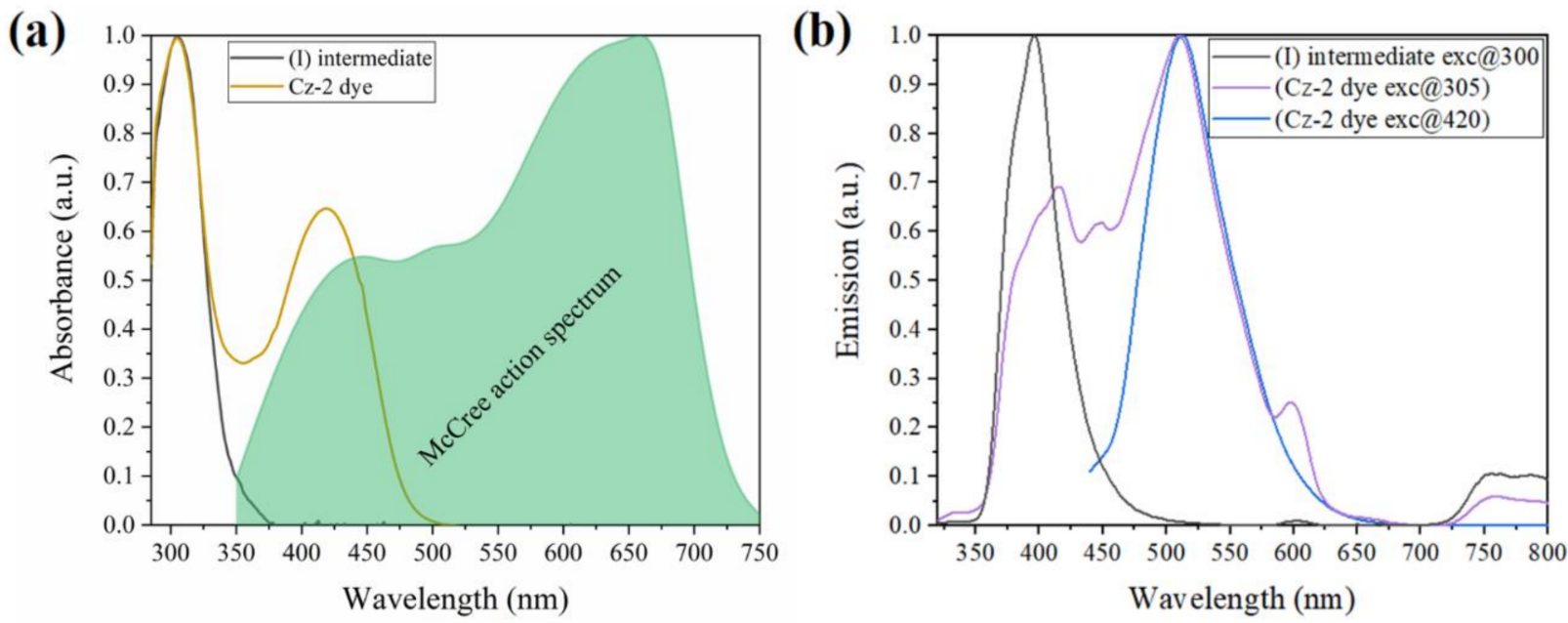

Figure 3. Optical characteristics of the (I) intermediate and Cz-2 dye in tetrahydrofuran (THF) solution: (a) UV-Vis spectra and (b) photoluminescence (PL) spectra after excitation at the respective absorption maxima.

(a)

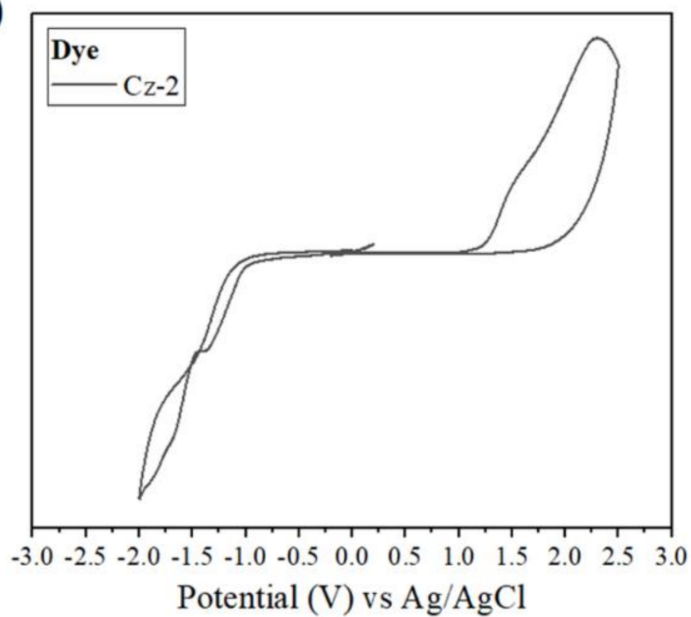

(b)

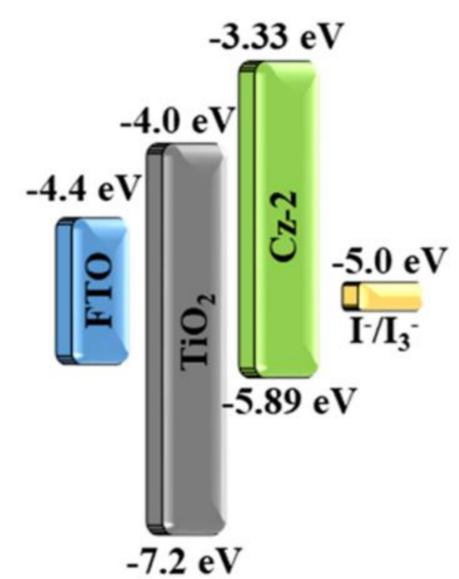

Figure 4. (a) Cyclic voltammogram of Cz-2 dye in the film form, (b) schematic representation of the energy levels of dye-sensitized solar cell (DSSC) components.

Table 1. Eg, opt., oxidation onset potential, highest occupied molecular orbital (HOMO), and lowest unoccupied molecular orbital (LUMO) energy levels of the Cz-2 dye in film form on fluorine-doped tin oxide (FTO) glass.

\begin{tabular}{cccccc}
\hline Dye & $E_{\text {g,opt }}(\mathrm{eV})$ & $\begin{array}{c}E_{\text {ons }}^{\text {ox }}, \mathrm{V} \\
(\mathrm{Ag} \text { vs. AgCl })\end{array}$ & $\begin{array}{c}E_{\text {ons, }}^{\text {red }} \mathbf{\mathrm { A }} \\
(\mathrm{Ag} \text { vs. AgCl) }\end{array}$ & $\begin{array}{c}\text { HOMO } \\
(\mathrm{eV})\end{array}$ & $\begin{array}{c}\text { LUMO } \\
(\mathrm{eV})\end{array}$ \\
\hline $\mathrm{Cz}-2$ & 2.56 & 1.24 & -1.10 & -5.89 & -3.33 \\
\hline
\end{tabular}


As it is observed, the LUMO level of the dye is higher than the conduction band of $\mathrm{TiO}_{2}$. Thus, the electron injection from the dye to the inorganic semiconductor is favored. On the other hand, the HOMO level of dye is more positive than the corresponding of the $\mathrm{I}^{-} / \mathrm{I}_{3}{ }^{-}$redox couple. Thus, the regeneration of the dye can also take place effectively.

\subsection{Characteristics of Dye-Sensitized Working Electrodes}

The DRS curve (Figure 5) of the Cz-2 dye was also recorded after its adsorption on thin $(15 \mu \mathrm{m})$ semitransparent $\mathrm{TiO}_{2}$ films, corresponding to those employed for the fabrication of the solar cells, using THF as a dye-adsorption solvent.

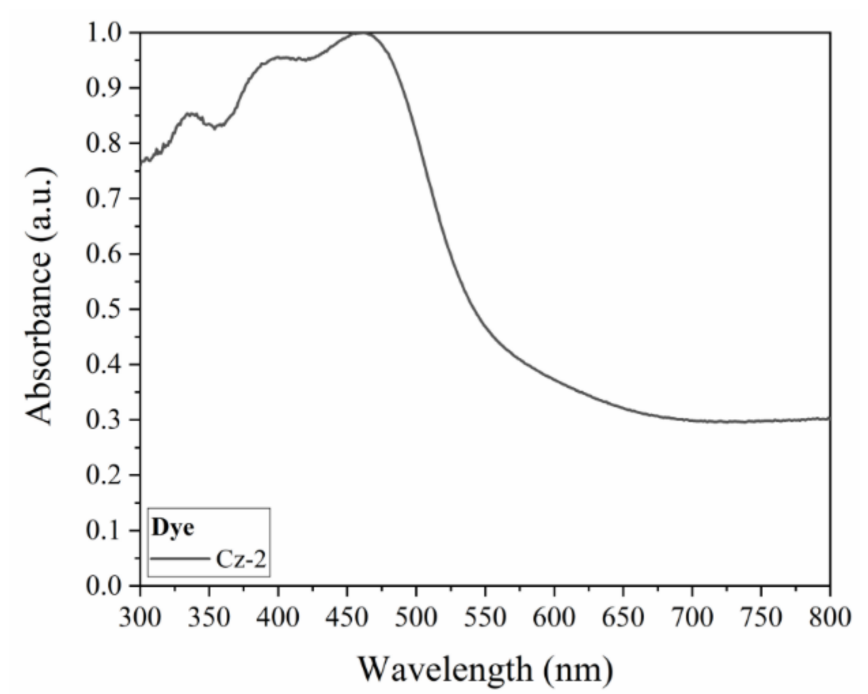

Figure 5. Diffuse reflectance spectroscopy (DRS) curve of the working electrode that was sensitized by the $\mathrm{Cz}-2$ dye.

As it is observed, the absorption spectrum of the $\mathrm{Cz}-2$ dye-sensitized working electrode is broad and located in the blue-green region of the visible light, while the absorption onset was found below $600 \mathrm{~nm}$, in contrast to the corresponding spectra that are usually obtained by the conventional ruthenium-based systems, where the absorption onset is found at much longer wavelengths [38]. This guarantees good transparency of dye-sensitized working electrodes in the red region of the visible light, which is the most important part of light for the photosynthetic action of the plants. The high absorbance in wavelengths longer than $600 \mathrm{~nm}$ is considered as an incompatible characteristic for sensitizers developed for greenhouses due to the high overlap with the second peak in the chlorophyll absorbance spectrum [36,39].

\subsection{Characteristics of the Solar Cells}

In order to evaluate the application of the Cz-2 dye to DSSCs, small-scale devices of $0.25 \mathrm{~cm}^{2}$ active area were fabricated and characterized. To determine a good balance between electric power generation and device transparency, a high performance $\mathrm{I}_{2}$-based electrolyte and a highly transparent $\mathrm{I}_{2}$-free electrolyte were tested as a material for the transport of charges from the cathode to the anode. Figure 6 shows the $J-V$ characteristic curves of the DSSCs that employed the $\mathrm{Cz}-2$ dye and $\mathrm{I}_{2}$-based or $\mathrm{I}_{2}$-free electrolyte, while the short-circuit current density $\left(J_{S C}\right)$, open-circuit voltage $\left(V_{O C}\right)$, fill factor $(F F)$, and energy conversion efficiency $(E C E)$ of the devices are tabulated in Table 2.

By comparing the electrical characteristics of the DSSCs, it is observed that the solar cells that employed the $\mathrm{Cz}-2$ dye demonstrated satisfactory results, taking into account the absorption spectrum of the dye, which is located in wavelengths below $600 \mathrm{~nm}$. The DSSCs that employed the synthesized organic dye demonstrated ECES on the order of $3.5 \%$ and $3.1 \%$, using the $\mathrm{I}_{2}$-based and the $\mathrm{I}_{2}$-free electrolyte, respectively. As it is observed, the usage 
of the $\mathrm{I}_{2}$-free electrolyte in DSSCs resulted in a small decrease in the ECE of the solar cells compared to the devices that employed the high-performance $\mathrm{I}_{2}$-based electrolyte, which was in the range of about $10 \%$. This decrease was mainly attributed to the decrease of $F F$, while the $J_{S C}$ and $V_{O C}$ were found higher when comparing the former devices with the latter ones.

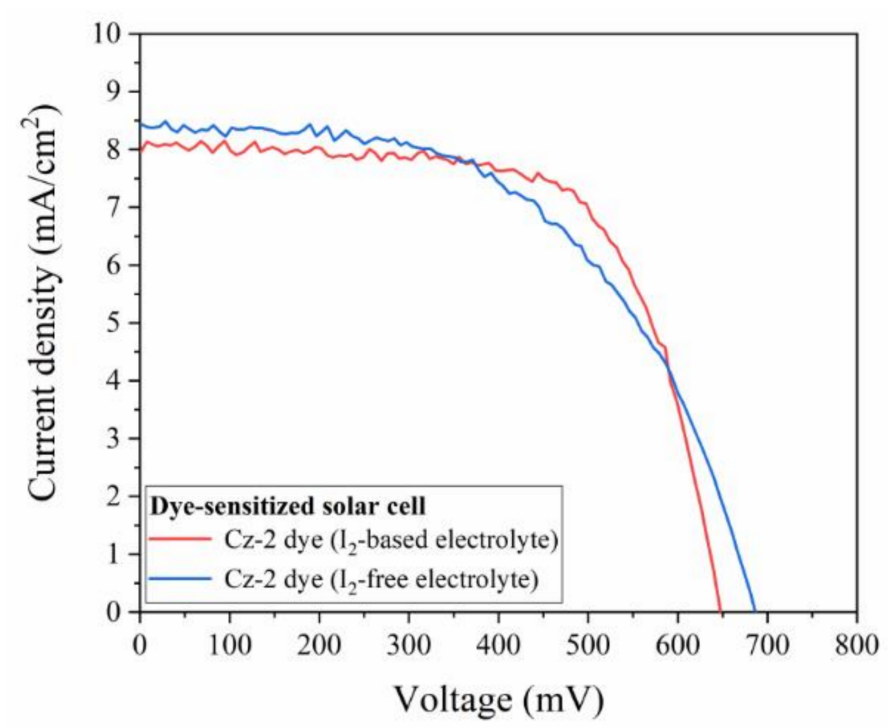

Figure 6. $J-V$ characteristic curves of the solar cells that employed the working electrodes that were sensitized by the $\mathrm{Cz}$-2 dye, using the $\mathrm{I}_{2}$-based or $\mathrm{I}_{2}$-free electrolyte.

Table 2. Electrical characteristics of the solar cells that employed the working electrodes that were sensitized by the $\mathrm{Cz}-2$ dye, using the $\mathrm{I}_{2}$-based or $\mathrm{I}_{2}$-free electrolyte.

\begin{tabular}{|c|c|c|c|c|c|}
\hline \multicolumn{2}{|c|}{ Solar Cell } & \multirow{2}{*}{$\begin{array}{c}J_{S C} \\
\left(\mathrm{~mA} / \mathrm{cm}^{2}\right)\end{array}$} & \multirow{2}{*}{$\begin{array}{l}V_{O C} \\
(\mathrm{mV})\end{array}$} & \multirow{2}{*}{$\begin{array}{l}F F \\
(-)\end{array}$} & \multirow{2}{*}{$\begin{array}{l}E C E \\
(\%)\end{array}$} \\
\hline Dye & Electrolyte & & & & \\
\hline $\mathrm{Cz}-2$ & $\mathrm{I}_{2}$-based & $8.02 \pm 0.05$ & $648 \pm 5$ & $0.68 \pm 0.02$ & $3.51 \pm 0.05$ \\
\hline $\mathrm{Cz}-2$ & $\mathrm{I}_{2}$-free & $8.50 \pm 0.32$ & $685 \pm 5$ & $0.54 \pm 0.03$ & $3.13 \pm 0.06$ \\
\hline
\end{tabular}

* The reported mean values and standard deviations were obtained by measuring three at least identical devices.

Figure 7 shows the IPCE spectra and the corresponding integrated $J_{S C}$ of the DSSCs that employed the Cz-2 dye, using $\mathrm{I}_{2}$-based or $\mathrm{I}_{2}$-free electrolyte. As it is observed, the solar cells showed a high external quantum efficiency in the blue-green region of the visible light, with the photo-current onset being in both cases at $575 \mathrm{~nm}$. The aforementioned agree with the DRS results, showing once again the suitability of the synthesized organic dye for greenhouse-oriented applications.

With a closer look at the IPCE spectra of the solar cells, it is observed that the usage of the $\mathrm{I}_{2}$-free electrolyte in the DSSCs results in an increase in their external quantum efficiency in the whole blue-green region of the visible light compared to the corresponding devices that employed the $\mathrm{I}_{2}$-based electrolyte. This observation was expected when considering the highly transparent nature of the former electrolyte, arising from the low concentration of triiodides near the dye-sensitized working electrode; the triiodides prevent light absorption by the dye, and thus, they lower the external quantum efficiency of the solar cells in that region [40]. At this point, it worth mentioning that the results coming from the IPCE characterization and $J-V$ characterization of the solar cells are in perfect agreement. In particular, the values of the integrated over the wavelengths $J_{S C}$ $\left(7.98 \mathrm{~mA} / \mathrm{cm}^{2}\right.$ and $8.47 \mathrm{~mA} / \mathrm{cm}^{2}$ for the device employing the iodide-based and iodidefree electrolyte, respectively)are almost equal to the corresponding ones of $J_{S C}$ determined from $J-V$ curves. 


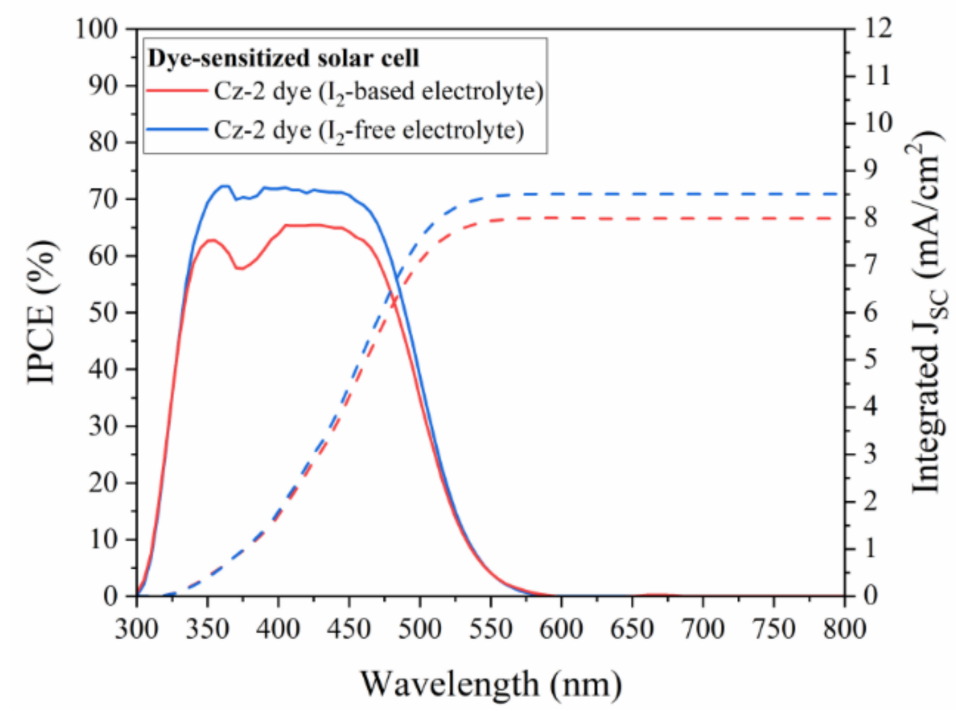

Figure 7. Incident photon-to-electron conversion efficiency (IPCE) curves of the solar cells that employed the working electrodes that were sensitized by the $\mathrm{Cz}-2$ dye, using the $\mathrm{I}_{2}$-based or $\mathrm{I}_{2}$ free electrolyte.

Additionally, the solar cells employing the $\mathrm{Cz}$-2 dye and the $\mathrm{I}_{2}$-based or $\mathrm{I}_{2}$-free electrolyte were characterized by means of EIS, to analyze the charge transfer processes taking place in the devices [41]. The Nyquist plots and the Bode phase diagrams are presented in Figure 8, while the parameters obtained by EIS are tabulated in Table 3. In the Nyquist plots (Figure 8a), due to the use of high-performance liquid state electrolytes, two semicircles were presented; the small semicircle at the higher frequency domain corresponds to charge transfer processes that take place at the $\mathrm{Pt} /$ electrolyte interface, while the larger one at the lower-frequency domain arises from the $\mathrm{TiO}_{2} /$ dye/electrolyte interface.

(a)

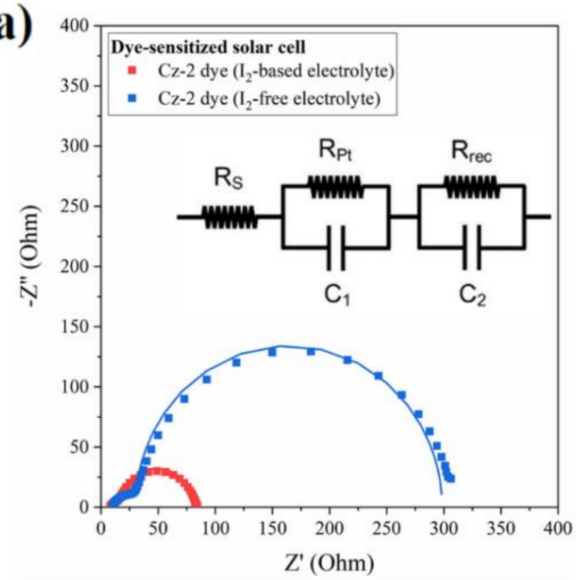

(b)

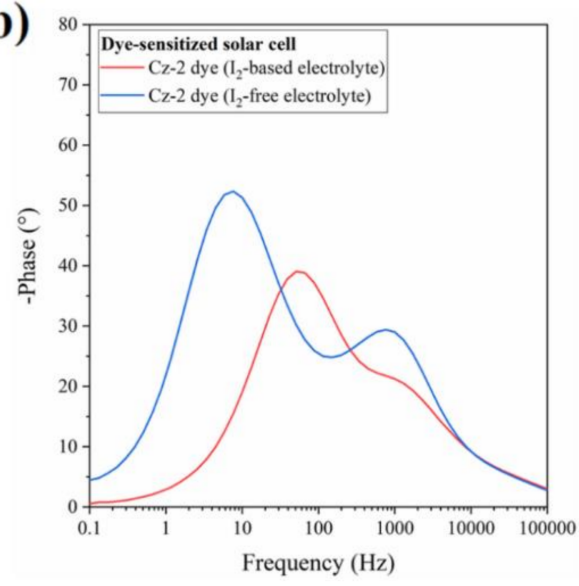

Figure 8. (a) Nyquist plots (inset the equivalent circuit) and (b) Bode phase diagrams for the solar cells that employed the working electrodes that were sensitized by the $\mathrm{Cz}-2$ dye, using the $\mathrm{I}_{2}$-based or $\mathrm{I}_{2}$-free electrolyte.

By fitting the experimental data with an equivalent circuit model, several parameters can be obtained, e.g., the series resistance of the solar cell $\left(R_{S}\right)$, the charge transfer resistance at the $\mathrm{Pt} /$ electrolyte interface $\left(R_{P t}\right)$, and the charge transfer resistance at the $\mathrm{TiO}_{2} /$ dye/electrolyte interface $\left(R_{r e c}\right)$. As it is observed, the values of the aforementioned parameters highly depend on the employed electrolyte ( $\mathrm{I}_{2}$-based or $\mathrm{I}_{2}$-free). The results showed that the solar cells that employed the $\mathrm{I}_{2}$-free electrolyte present higher values of $R_{s}$ $R_{P t}$, and $R_{r e c}$ compared to the corresponding devices employing the $\mathrm{I}_{2}$-based electrolyte, 
underlying a higher charge transport resistance but a lower recombination rate inside the solar cells in the former case compared to the latter. Considering the Bode phase plots (Figure $8 \mathrm{~b}$ ), the frequency of the peaks observed in the middle-frequency domain can be used to determine the electron lifetime within the photo-anode $\left(\tau_{e}\right)$, which can be considered as another indication of the charge recombination rate taking place at the $\mathrm{TiO}_{2}$ /dye/electrolyte interface. In agreement with the previous discussion, the solar cells that employed the $\mathrm{I}_{2}$-free electrolyte demonstrate a much higher value of $\tau_{e}$ compared to the device employing the $\mathrm{I}_{2}$-based electrolyte.

Table 3. Parameters obtained from the electrochemical impedance spectroscopy (EIS) measurements for the solar cells that employed the working electrodes that were sensitized by the Cz-2 dye, using the $\mathrm{I}_{2}$-based or $\mathrm{I}_{2}$-free electrolyte.

\begin{tabular}{|c|c|c|c|c|c|}
\hline \multicolumn{2}{|c|}{ Solar Cell } & \multirow{2}{*}{$\begin{array}{c}R_{s} \\
(\mathrm{Ohm})\end{array}$} & \multirow{2}{*}{$\begin{array}{c}R_{P t} \\
(\mathrm{Ohm})\end{array}$} & \multirow{2}{*}{$\begin{array}{c}R_{r e c} \\
(\mathrm{Ohm})\end{array}$} & \multirow{2}{*}{$\begin{array}{c}\tau_{e} \\
(\mathrm{~ms})\end{array}$} \\
\hline Dye & Electrolyte & & & & \\
\hline $\mathrm{Cz}-2$ & $\mathrm{I}_{2}$-based & 8.7 & 8 & 65 & 2.9 \\
\hline $\mathrm{Cz}-2$ & $\mathrm{I}_{2}$-free & 10.8 & 20 & 268 & 19.9 \\
\hline
\end{tabular}

* for $V=V_{O C}$ in dark.

As indicated in the literature, the charge recombination rate and electron lifetime at the $\mathrm{TiO}_{2} /$ dye/electrolyte interface of DSSCs are influenced by many factors, including the dye molecules size and geometry, dye adsorption behavior, and the number of triiodides presented near this interface, which in turn influence the photo-voltage of the solar cells $[40,42]$. Indeed, in the present investigation, the variation of the values of $R_{r e c}$ and $\tau_{e}$ agreed with the one of the $V_{O C}$ obtained from the characterization of the solar cells. The higher values of $R_{r e c}$ and $\tau_{e}$, and subsequently of $V_{O C}$ obtained by the application of the $\mathrm{I}_{2}$-free electrolyte in DSSCs compared to the corresponding devices employing the $\mathrm{I}_{2}$-based electrolyte arises from the much lower concentration of triiodides existing near the $\mathrm{TiO}_{2} /$ dye/electrolyte interface in the former case [40]. The reduction of triiodides to iodides by the electrons of the anode semiconductor is considered one of the main reasons for dark current in DSSCs. The low concentration of triiodides in $\mathrm{I}_{2}$-free electrolyte, and the subsequent lower conductivity of this electrolyte compared to the corresponding one of the $\mathrm{I}_{2}$-based electrolyte, is also considered the reason for the increased values of $R_{S}$ and $R_{P t}$ observed in the devices employing the former electrolyte $[40,43]$.

The transparency in the PAR region of a PV device when it is intended to be implemented as a cladding material of greenhouses is of the greatest importance. In this case, metrics such as crop growth factor $(G)$ are used to evaluate the subsequent impact of the cladding material on the growth of plants. $G$ determines the ratio of the rate of photosynthesis under the greenhouse cladding material (the DSSCs for the present case) and the rate of photosynthesis under the full sun. $G$ can be calculated by Equation (4), where $T(\lambda)$ is the transmittance spectra of the cladding material, $b_{s}(\lambda)$ is the AM 1.5 incident solar irradiance, and $a(\lambda)$ is the action spectrum of plants [44]. In the present study, the plants action spectrum was obtained from an average action spectrum of 22 plants (McCree curve) [36].

$$
G=\frac{\int T(\lambda) b_{s}(\lambda) a(\lambda) d \lambda}{\int b_{s}(\lambda) a(\lambda) d \lambda}
$$

As it is observed from Figure 9, the DSSCs demonstrated high transparency, which exceeded $50 \%$ in the red region of the visible light, for both types of devices. The calculated transmittance of the solar cells in the PAR region ranged higher than $25 \%$ and the crop growth factor higher than $30 \%$, demonstrating their suitability for greenhouses integration. The usage of the $\mathrm{I}_{2}$-free electrolyte in DSSCs resulted in a $10 \%$ increase of the values of the aforementioned metrics compared to the corresponding case of usage of the conventional $\mathrm{I}_{2}$-based electrolyte. The present study demonstrates that the development of DSSCs with a 35\% crop growth factor combined with efficiencies higher than $3 \%$ is feasible. These combined performance parameters are considered promising for the further development 
of transparent "agrivoltaics", proving that DSSCs can be a good competitor to other established and emerging PV technologies that are intended to be used as greenhouse cladding materials [44,45].

(a)

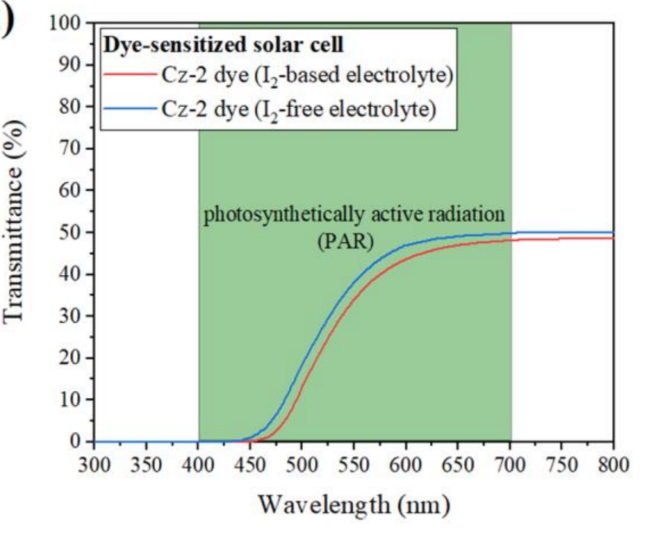

(b)

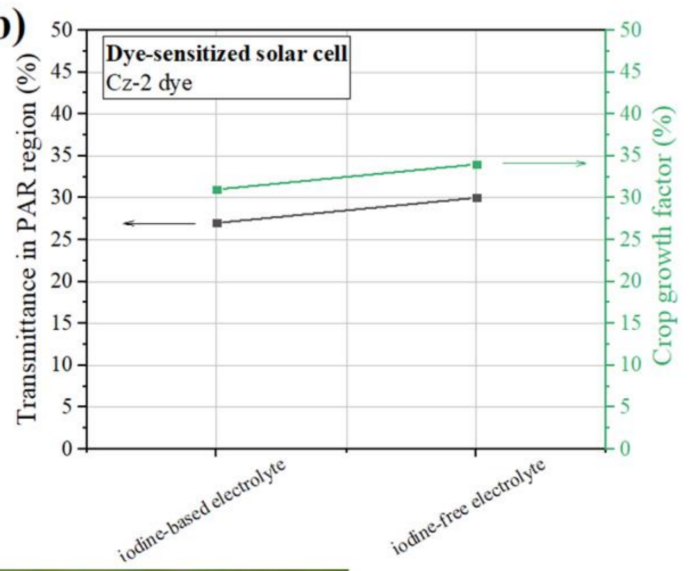

(c)

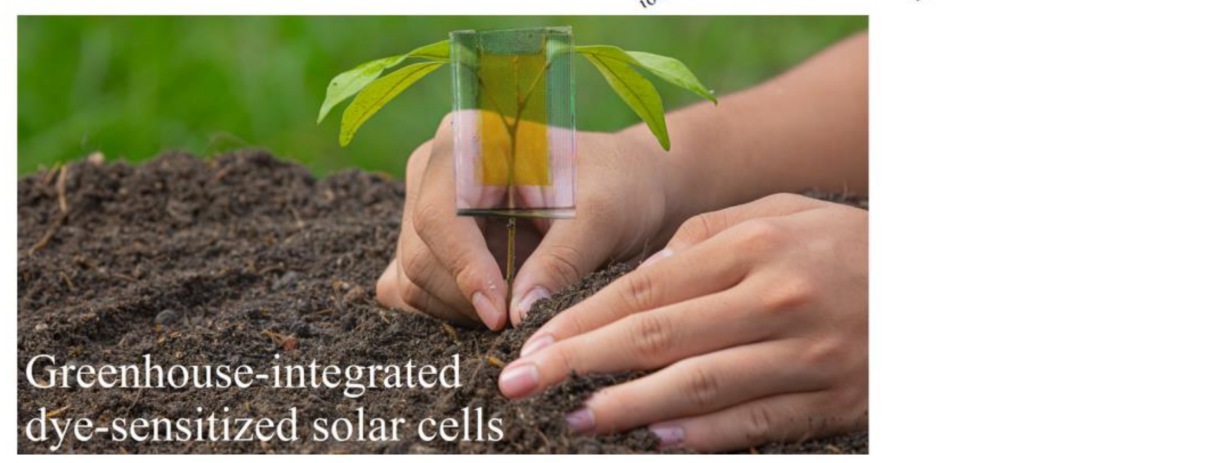

Figure 9. (a) Transmittance spectra, (b) transmittance in the photosynthetically active radiation (PAR) region and crop growth factor for the solar cells that employed the working electrodes that were sensitized by $\mathrm{Cz}-2$ dye, using the $\mathrm{I}_{2}$-based or $\mathrm{I}_{2}$-free electrolyte, and (c) digital photo showing the transparency of the spectral engineered DSSCs (the background photo was taken from www.freepik.com, free license for personal and commercial purpose).

\section{Conclusions}

Greenhouse-integrated PVs are the global trend in our days, allowing a vast urban area to produce both food and sustainable energy. In this concept, DSSCs constitute a unique competitor to other established PV technologies since they are offer distinct advantages, such as high transparency, large area coverage, very good performance in diffuse light conditions, and low cost. The present study proposes a new low-cost organic dye that is specially synthesized for greenhouses-integrated DSSCs to achieve a good balance between light-to-electricity generation and device transparency in the PAR region, which is needed for the photosynthetic action of the plants. The dye shows an intense blue light absorption and an absorption onset below $500 \mathrm{~nm}$, allowing a high transmittance in the red region of the visible light, even after its adsorption on the anode semiconductor.

The application of the dye to DSSCs was evaluated both for the usage of a highperformance $\mathrm{I}_{2}$-based electrolyte or a highly transparent $\mathrm{I}_{2}$-free electrolyte. The results showed that both types of devices demonstrate a high external quantum efficiency (even higher than $70 \%$ ) in the whole blue-green region of the visible light and high transparency (up to 55\%) in longer wavelengths, demonstrating their suitability for application as greenhouses cladding materials. The usage of the highly transparent $\mathrm{I}_{2}$-free electrolyte in DSSCs, arising from the low concentration of triiodides in its composition, led to a much higher absorption of light by the dye in the whole blue-green region of visible light compared to the solar cells employing the conventional yellowship $\mathrm{I}_{2}$-based electrolyte and significantly increased the transparency of the device in the PAR region. At the same time, 
it led to a much lower charge recombination rate inside the solar cells and thus, to higher photo-voltage production, maintaining the ECE of DSSCs at high levels, almost at $90 \%$ of the efficiency attained by the corresponding devices employing the high performance $\mathrm{I}_{2}$-based electrolyte. The results of the present work demonstrate that the development of DSSCs with an almost 35\% crop growth factor combined with efficiencies higher than $3 \%$ is feasible, shedding light on ways for the further development of greenhouse-integrated DSSCs.

Author Contributions: All authors have contributed to the ideas, experimental part, and data analysis, as well as to the preparation of the paper. All authors have read and agreed to the submitted version of the manuscript.

Funding: Financial support from the project: "Research and Development Plan of Efficient and Low Cost Photovoltaic (P/V) Glass Panels, BRITE-PVGlass" (FR/MIS: 80399/5021436) of the "Supporting Small and Medium Enterprises for research projects in the fields 'Microelectronics' and 'Advanced Materials' (1b.1.1) of the Operational Program “WEST GREECE 2014-2020" co-funded by Greece and the European Union is greatly acknowledged.

Acknowledgments: The Instrumental Analysis Laboratory (IAL) of University of Patras is greatly acknowledged for the NMR spectra recorded in its facilities.

Conflicts of Interest: The authors declare no conflict of interest. The funders had no role in the design of the present investigation; in the collection, analysis, and interpretation of the data; in writing of the manuscript, and in deciding to publish the results.

\section{References}

1. Usman, M.; Farooq, M.; Wakeel, A.; Nawaz, A.; Cheema, S.A.; ur Rehman, H.; Ashraf, I.; Sanaullah, M. Nanotechnology in agriculture: Current status, challenges and future opportunities. Sci. Total Environ. 2020, 721, 137778. [CrossRef]

2. U.S. Energy Information Administration. Today in Energy. Available online: https://www.eia.gov/todayinenergy/detail.php? id $=41433$ (accessed on 15 January 2021).

3. Hassanien, R.H.E.; Li, M.; Dong Lin, W. Advanced applications of solar energy in agricultural greenhouses. Renew. Sustain. Energy Rev. 2016, 54, 989-1001. [CrossRef]

4. Ravishankar, E.; Booth, R.E.; Saravitz, C.; Sederoff, H.; Ade, H.W.; O'Connor, B.T. Achieving net zero energy greenhouses by integrating semitransparent organic solar cells. Joule 2020, 4, 490-506. [CrossRef]

5. Cossu, M.; Murgia, L.; Ledda, L.; Deligios, P.A.; Sirigu, A.; Chessa, F.; Pazzona, A. Solar radiation distribution inside a greenhouse with south-oriented photovoltaic roofs and effects on crop productivity. Appl. Energy 2014, 133, 89-100. [CrossRef]

6. Roslan, N.; Ya'acob, M.E.; Radzi, M.A.M.; Hashimoto, Y.; Jamaludin, D.; Chen, G. Dye sensitized solar cell (DSSC) greenhouse shading: New insights for solar radiation manipulation. Renew. Sustain. Energy Rev. 2018, 92, 171-186. [CrossRef]

7. O'Regan, B.; Grätzel, M. A low-cost, high-efficiency solar cell based on dye-sensitized colloidal TiO 2 films. Nature 1991, 353, 737-740. [CrossRef]

8. Gong, J.; Sumathy, K.; Qiao, Q.; Zhou, Z. Review on dye-sensitized solar cells (DSSCs): Advanced techniques and research trends. Renew. Sustain. Energy Rev. 2017, 68, 234-246. [CrossRef]

9. Dessì, A.; Chalkias, D.A.; Bilancia, S.; Sinicropi, A.; Calamante, M.; Mordini, A.; Karavioti, A.; Stathatos, E.; Zani, L.; Reginato, G. $\mathrm{D}-\mathrm{A}-\pi$-A organic dyes with tailored green light absorption for potential application in greenhouse-integrated Dye-Sensitized Solar Cells. Sustain. Energy Fuels 2021. [CrossRef]

10. Dessì, A.; Calamante, M.; Sinicropi, A.; Parisi, M.L.; Vesce, L.; Mariani, P.; Taheri, B.; Ciocca, M.; Di Carlo, A.; Zani, L.; et al. Thiazolo [5,4-d] thiazole-based organic sensitizers with improved spectral properties for application in greenhouse-integrated dye-sensitized solar cells. Sustain. Energy Fuels 2020, 4, 2309-2321. [CrossRef]

11. Duvva, N.; Raptis, D.; Kumar, C.V.; Koukaras, E.N.; Giribabu, L.; Lianos, P. Design of diketopyrrolopyrrole chromophores applicable as sensitizers in dye-sensitized photovoltaic windows for green houses. Dye. Pigment. 2016, 134, 472-479. [CrossRef]

12. Kim, J.-J.; Kang, M.; Kwak, O.K.; Yoon, Y.-J.; Min, K.S.; Chu, M.J. Fabrication and characterization of dye-sensitized solar cells for greenhouse application. Int. J. Photoenergy 2014, 2014. [CrossRef]

13. Mishra, A.; Fischer, M.K.R.; Bäuerle, P. Metal-free organic dyes for dye-sensitized solar cells: From structure: Property relationships to design rules. Angew. Chemie Int. Ed. 2009, 48, 2474-2499. [CrossRef] [PubMed]

14. Chu, H.-C.; Sahu, D.; Hsu, Y.-C.; Padhy, H.; Patra, D.; Lin, J.-T.; Bhattacharya, D.; Lu, K.-L.; Wei, K.-H.; Lin, H.-C. Structural planarity and conjugation effects of novel symmetrical acceptor-donor-acceptor organic sensitizers on dye-sensitized solar cells. Dye. Pigment. 2012, 93, 1488-1497. [CrossRef]

15. Lee, Y.H.; Yun, H.J.; Choi, S.K.; Yang, Y.S.; Park, T.; Ahn, K.-S.; Suresh, T.; Kim, J.H. Triphenylamine-based tri-anchoring organic dye with enhanced electron lifetime and long-term stability for dye sensitized solar cells. Synth. Met. 2016, 217, 248-255. [CrossRef] 
16. Huang, Z.-S.; Meier, H.; Cao, D. Phenothiazine-based dyes for efficient dye-sensitized solar cells. J. Mater. Chem. C 2016, 4, 2404-2426. [CrossRef]

17. Wu, Y.; Zhang, X.; Li, W.; Wang, Z.-S.; Tian, H.; Zhu, W. Hexylthiophene-featured D-A- $\pi$-A structural indoline chromophores for coadsorbent-free and panchromatic dye-sensitized solar cells. Adv. Energy Mater. 2012, 2, 149-156. [CrossRef]

18. Xie, X.; Sun, D.; Wei, Y.; Yuan, Y.; Zhang, J.; Ren, Y.; Wang, P. Thienochrysenocarbazole based organic dyes for transparent solar cells with over 10\% efficiency. J. Mater. Chem. A 2019, 7, 11338-11346. [CrossRef]

19. Zhang, L.; Yang, X.; Wang, W.; Gurzadyan, G.G.; Li, J.; Li, X.; An, J.; Yu, Z.; Wang, H.; Cai, B.; et al. 13.6\% efficient organic dye-sensitized solar cells by minimizing energy losses of the excited state. ACS Energy Lett. 2019, 4, 943-951. [CrossRef]

20. Uoyama, H.; Goushi, K.; Shizu, K.; Nomura, H.; Adachi, C. Highly efficient organic light-emitting diodes from delayed fluorescence. Nature 2012, 492, 234-238. [CrossRef]

21. Wakim, S.; Beaupré, S.; Blouin, N.; Aich, B.-R.; Rodman, S.; Gaudiana, R.; Tao, Y.; Leclerc, M. Highly efficient organic solar cells based on a poly(2,7-carbazole) derivative. J. Mater. Chem. 2009, 19, 5351-5358. [CrossRef]

22. Tsutsumi, N. Molecular design of photorefractive polymers. Polym. J. 2016, 48, 571-588. [CrossRef]

23. An, J.; Yang, X.; Cai, B.; Zhang, L.; Yang, K.; Yu, Z.; Wang, X.; Hagfeldt, A.; Sun, L. Fine-tuning by triple bond of carbazole derivative dyes to obtain high efficiency for dye-sensitized solar cells with copper electrolyte. ACS Appl. Mater. Interfaces 2020. [CrossRef]

24. Liu, X.; Zhang, Y.; Fei, X.; Liao, L.; Fan, J. 9,9'-bicarbazole: New molecular skeleton for organic light-emitting diodes. Chem. A Eur. J. 2019, 25, 4501-4508. [CrossRef]

25. Yuan, Y.; Huang, H.; Chen, L.; Chen, Y. N,N'-bicarbazole: A versatile building block toward the construction of conjugated porous polymers for $\mathrm{CO}_{2}$ capture and dyes adsorption. Macromolecules 2017, 50, 4993-5003. [CrossRef]

26. Feng, S.; Xu, H.; Zhang, C.; Chen, Y.; Zeng, J.; Jiang, D.; Jiang, J.X. Bicarbazole-based redox-active covalent organic frameworks for ultrahigh-performance energy storage. Chem. Commun. 2017, 53, 11334-11337. [CrossRef]

27. Kakiage, K.; Aoyama, Y.; Yano, T.; Otsuka, T.; Kyomen, T.; Unno, M.; Hanaya, M. An achievement of over 12 percent efficiency in an organic dye-sensitized solar cell. Chem. Commun. 2014, 50, 6379-6381. [CrossRef] [PubMed]

28. Senthilkumar, K.; Kondratowicz, M.; Lis, T.; Chmielewski, P.J.; Cybińska, J.; Zafra, J.L.; Casado, J.; Vives, T.; Crassous, J.; Favereau, L.; et al. Lemniscular [16] cycloparaphenylene: A radially conjugated figure-eight aromatic molecule. J. Am. Chem. Soc. 2019, 141, 7421-7427. [CrossRef]

29. Coulson, D.R.; Satek, L.C.; Grim, S.O. Tetrakis(triphenylphosphine)palladium(0). In Inorganic Syntheses; Cotton, F.A., Ed.; Wiley Online Library: Hoboken, NJ, USA, 1972; Volume 13, pp. 121-124.

30. Chalkias, D.A.; Laios, A.I.; Petala, A.; Papanicolaou, G.C. Evaluation of the limiting factors affecting large-sized, flexible, platinum-free dye-sensitized solar cells performance: A combined experimental and equivalent circuit analysis. J. Mater. Sci. Mater. Electron. 2018, 29, 9621-9634. [CrossRef]

31. Yan, Y.; Wang, J.; Chang, Q.; Babikier, M.; Wang, H.; Li, H.; Yu, Q.; Gao, S.; Jiao, S. Fabrication of mesoporous TiO 2 electrodes by chemical technique for dye-sensitized solar cells. Electrochim. Acta 2013, 94, 277-284. [CrossRef]

32. Wang, Z.-S.; Kawauchi, H.; Kashima, T.; Arakawa, H. Significant influence of $\mathrm{TiO}_{2}$ photoelectrode morphology on the energy conversion efficiency of N719 dye-sensitized solar cell. Coord. Chem. Rev. 2004, 248, 1381-1389. [CrossRef]

33. Chalkias, D.A.; Giannopoulos, D.I.; Kollia, E.; Petala, A.; Kostopoulos, V.; Papanicolaou, G.C. Preparation of polyvinylpyrrolidonebased polymer electrolytes and their application by in-situ gelation in dye-sensitized solar cells. Electrochim. Acta 2018, 271, 632-640. [CrossRef]

34. Ito, S.; Nazeeruddin, M.K.; Liska, P.; Comte, P.; Charvet, R.; Péchy, P.; Jirousek, M.; Kay, A.; Zakeeruddin, S.M.; Grätzel, M. Photovoltaic characterization of dye-sensitized solar cells: Effect of device masking on conversion efficiency. Prog. Photovolt. Res. Appl. 2006, 14, 589-601. [CrossRef]

35. Neugebauer, F.A.; Fischer, H.; Bamberger, S.; Smith, H.O. Aminyle, 6. tert.-butyl-substituierte 9-carbazolyl-radikale, carbazolradikalkationen und carbazol-9-oxyl-radikale. Chem. Ber. 1972, 105, 2694-2713. [CrossRef]

36. McCree, K.J. The action spectrum, absorptance and quantum yield of photosynthesis in crop plants. Agric. Meteorol. 1971, 9 , 191-216. [CrossRef]

37. Gupta, K.S.V.; Suresh, T.; Singh, S.P.; Islam, A.; Han, L.; Chandrasekharam, M. Carbazole based A- $\pi$-D- $\pi$-A dyes with double electron acceptor for dye-sensitized solar cell. Org. Electron. 2014, 15, 266-275. [CrossRef]

38. Kalyanasundaram, K. Dye-sensitized solar cells, 1st ed.; Taylor and Francis Group LLC: Lausanne, Switzerland, 2010.

39. Inada, K. Action spectra for photosynthesis in higher plants. Plant Cell Physiol. 1976, 17, 355-365.

40. Ri, J.H.; Jin, J.; Xu, J.; Peng, T.; Ryu, K. Il Preparation of iodine-free ionic liquid gel electrolyte using polyethylene oxide (PEO)polyethylene glycol (PEG) and its application in Ti-foil-based dye-sensitized solar cells. Electrochim. Acta 2016, 201, 251-259. [CrossRef]

41. Sacco, A. Electrochemical impedance spectroscopy: Fundamentals and application in dye-sensitized solar cells. Renew. Sustain. Energy Rev. 2017, 79, 814-829. [CrossRef]

42. Dessì, A.; Calamante, M.; Mordini, A.; Peruzzini, M.; Sinicropi, A.; Basosi, R.; Fabrizi De Biani, F.; Taddei, M.; Colonna, D.; di Carlo, A.; et al. Thiazolo[5,4-d]thiazole-based organic sensitizers with strong visible light absorption for transparent, efficient and stable dye-sensitized solar cells. RSC Adv. 2015, 5, 32657-32668. [CrossRef] 
43. Yu, W.-C.; Lin, L.-Y.; Chang, W.-C.; Zhong, S.-H.; Su, C.-C. Iodine-free nanocomposite gel electrolytes for quasi-solid-state dye-sensitized solar cells. J. Power Sources 2018, 403, 157-166. [CrossRef]

44. Shi, H.; Xia, R.; Zhang, G.; Yip, H.-L.; Cao, Y. Spectral engineering of semitransparent polymer solar cells for greenhouse applications. Adv. Energy Mater. 2019, 9, 1803438. [CrossRef]

45. Emmott, C.J.M.; Röhr, J.A.; Campoy-Quiles, M.; Kirchartz, T.; Urbina, A.; Ekins-Daukes, N.J.; Nelson, J. Organic photovoltaic greenhouses: A unique application for semi-transparent PV? Energy Environ. Sci. 2015, 8, 1317-1328. [CrossRef] 